Al-Madrasah: Jurnal Ilmiah Pendidikan Madrasah Ibtidaiyah

Vol. 5, No. 2, 2021

DOI 10.35931/am.v5i2.414

P-ISSN: 2620-5807; E-ISSN: 2620-7184

\title{
PENGARUH SUPERVISI KEPALA MADRASAH DAN KOMPETENSI GURU TERHADAP KINERJA GURU DI MADRASAH IBTIDAIYAH NEGERI SE-KABUPATEN SAMBAS
}

\author{
Arnadi $^{1}$, Purniadi Putra ${ }^{2} \operatorname{Hamdah}^{3}$ \\ 12 Institut Agama Islam Sultan Muhammad Syafiuddin Sambas, \\ Indonesia \\ ${ }^{3}$ Kepala Madrasah Ibtidaiyah Negeri 2 Sambas Kabupaten Sambas, \\ Indonesia \\ Email: putrapurniadi@gmail.com
}

\section{Abstrak}

Tujuan dalam penelitian; mendiskripsikan dan menganalisis dari hasil penelitian MIN Se-Kabupaten Sambas yang berjumlah 68 guru. Pengumpulan data dengan metode kuesioner. Uji validitas instrumen dengan teknik analisis product moment, sedangkan uji reliabilitas dengan koefisien alpha. Teknik analisis data menggunakan analisis regresi berganda. Sebelum analisis data terlebih dahulu diadakan pengujian persyaratan analisis uji normalitas. Hasil penelitian menunjukkan bahwa: (1) terdapat pengaruh supervisi kepala madrasah terhadap kinerja guru dengan nilai signifikansi sebesar 0.029 dan besarnya pengaruh 0.070 (7\%) (2) memiliki nilai signifikansi sebesar $0.459(45.90 \%)$ dan (3) terdapat pengaruh positif dan signifikan secara simultan signifikansinya sebesar 0.00 dan 0.521 (52.10\%) artinya pengaruh antara variable supervisi kepala madrasah dan kompetensi guru $\left(X_{2}\right)$ terhadap kinerja guru $(Y)$ artinya memiliki kekutan tinggi. Implikasi penelitian ini pentingnya peningkatan kinerja guru yaitu peningkatan supervisi kepala madrasah harus dilakukan dengan baik baik dari perencanaan supervisi, pelaksanaan supervisi serta tindak lanjut supervisi sehingga guru mendapatkan pembinaan, perhatian dan pengawasan yang baik, dan merasakan bahwa dengan adanya supervisi kepala madrasah, guru dapat meningkatkan kompetensi dan kinerjanya. Semakin baik supervisi kepala madrasah yang dilakukan maka akan semakin baik pula kompetensi dan kinerja guru.

Kata Kunci: Supervisi Kepala Madrasah, Kompetensi Guru dan Kinerja Guru

\section{PENDAHULUAN}

Dendidikan memiliki integrasi yang salin berkaitan antara satu dengan yang lainnya. Perubahan perkembangan pendidikan kepada siswa agar memiliki 
Arnadi, Purniadi Putra, Hamidah : Pengaruh Supervisi Kepala Madrasah dan Kompetensi Guru Terhadap Kinerja Guru Madrasah Ibtidaiyah Negeri seKabupaten Sambas

kontribusi pada aspek nilai-nilai pendidikan karakter yang diajarkan oleh setiap guru. Komponen yang sangat penting adalah guru yang menjadi ujung tombak dalam peningkatan kualitas pendidikan. Berapa pun besarnya investasi yang ditanamkan untuk memperbaiki mutu pendidikan, tanpa kehadiran guru dan dosen yang kompeten, profesional, bermartabat, dan sejahtera dapat dipastikan tidak akan tercapai. ${ }^{1}$

Hal yang terjadi saat ini adanya pradigma bagi masyarakat bahwa menjadi guru merupakan hal yang mudah asalkan guru tersebut berpengetahuan. Menurut Nana Sudjana ${ }^{2}$ persepsi masyarakat mengangap guru ini memiliki keahlian yang lebih rendah dibandingkan dengan profesi lain adanya alasan sebagai berikut: pertama; pandangan setiap masyarakat yang menjadi guru itu syaratnya memiliki pengetahuan, kedua; memiliki kekurangan dari saranaprasarana pada daerah 3T, dan ketiga; guru masih belum mengerti tentang pentingnya profesi yang dimilikinya.

Pandangan manajemen SDM dalam peningkatan kualitas guru masih terasa belum efektif dan memiliki beberapa unsur kekurangan dalam tatatanan sistem pendidikan baik dari unsur penerimaan guru, pengangkatan guru dan lain sebagainya. Belum adanya pemerataan antara kebutuhan yang diperlukan serta belum adanya dukungan yang merata pada aspek sarana prasarana. ${ }^{3}$ Berdasarkan hasil penelitian Riska dan Sukmawati ${ }^{4}$ menyebutkan dalam kegiatan supervisi masih belum maksimal yang dilakukan oleh kepala sekolah tidak terlalu subjektif dalam memberikan penilaian, masih terdapat pemberian penghargaan kepada tim penilai yang belum menunjukkan keprofesional guru, kurangnya kedisiplinan bagi guru, supervisi hanya sebatas formalitas saja, sehingga guru merasa tidak memiliki rasa tanggung jawab yang penuh dalam mengikuti supervisi sekolah.

Selain itu juga keberhasian suatu pendidikan dipengaruhi oleh beberapa faktor diantaranya memiliki guru berkualitas, siswa, fasilitas yang memadai, lingkungan dan kurikulum. ${ }^{5}$ Menurut Gary dan Margaret ${ }^{6}$ menyebutkan bahwa

\footnotetext{
1 Tentang Guru dan Nomor. 14 Tahun 2005, Dosen, Undang-Undang R.I (Jakarta, 2005), p. 2.

${ }^{2}$ Moh Uzer Usman, Menjadi Guru Profesional (Bandung: PT Remaja Rosdakarya, 2010).

${ }^{3}$ Da'i Wibowo, 'Kompetensi Pedagogik Guru Terhadap Kinerja Guru' (Universitas Negeri Semarang, 2009).

${ }^{4}$ Riska Mawarni and Chiar Sukmawati, 'Supervisi Akademik Di Sekolah Menengah Atas Negeri 1 Pemangkat Kabupaten Sambas', Pendidikan Dan Pembelajaran Khatulistiwa, 6.1 (2017), 1-17.

${ }^{5}$ Nana Sudjana, Dasar-Dasar Proses Belajar Mengajar (Bandung: Sinar Baru, 2002).
}

Al-Madrasah: Jurnal Ilmiah Pendidikan Madrasah Ibtidaiyah

Vol. 5, No. 2, Januari-Juni 2021 
Arnadi, Purniadi Putra, Hamidah : Pengaruh Supervisi Kepala Madrasah dan Kompetensi Guru Terhadap Kinerja Guru Madrasah Ibtidaiyah Negeri seKabupaten Sambas

guru yang memiliki kompetensi dan efektif secara profesional memiliki ciri khas diantaranya; (1) memiliki kemampuan menciptakan iklim belajar yang kondusif, (2) kemampuan mengembangkan strategi dan manajemen pembelajaran, (3) memiliki kemampuan memberikan umpan balik (feedback) dan penguatan (reinforcement) dan (4) memiliki kemampuan peningkatan diri.

Keberhasilan guru di sekolah merupakan campur tangan dari seorang kepala sekolah yang selalu memberikan pembinaan terhadap guru dalam mengalami kesulitan baik dari manajemen kelas, pengajaran dan lain sebagainya. Kepala Sekolah/Madrasah memiliki peran penting yang bertanggung jawab atas jalannya sistem pendidikan di madrasah. Salah satu tugas dan tanggung jawab kepala madrasah terhadap para tenaga pendidiknya yaitu mampu meningkatkan kinerja guru. Dalam Piet A. Sahertian ${ }^{7}$ mengatakan bahwa tugas dan tanggung jawab kepala madrasah untuk masa yang akan datang meliputi 4 sebagian besar diantaranya pembinaan kurikulum, perbaikan proses pembelajaran, pengembangan staf, pemeliharaan dan perawatan moral serta semangat kerja guru.

Berdasarkan dari pernyataan di atas dalam meningkatkan kualitas mutu pendidikan maka diperlukan adanyan supervisi kepala madrasah bagi guru untuk memberikan bimbingan dalam peningkatan kompetensi guru dalam mengajar di kelas sehingga dapat memberikan pengetahuan dan keahlian pengajaran. Dengan adanya kegiatan supervisi kepala madrasah yang dilaksanakan di sekolah maka problem guru baik administrasi, kegiatan pembelajaran serta personal akan dapat terbantu sehinggan kualitas pendidikan akan tercapai dan bermutu. Menurut Piet A. Saherian dan Frans Mataheru ${ }^{8}$ supervisi kepala madrasah yang baik mengarahkan perhatiannya kepada dasardasar pendidikan dan cara-cara belajar serta pengembangannya dalam pencapaian tujuan umum pendidikan, di mana tujuan supervisi adalah untuk menciptakan situasi belajar-mengajar yang baik. Usaha ke arah perbaikan belajar mengajar ditujukan kepada pencapaian tujuan akhir dari pendidikan yaitu pembentukan pribadi anak secara maksimal.

Madrasah Ibtidaiyah Negeri Kabupaten Sambas terdiri dari tiga Madrasah dalam memiliki pola kepemimpinan baik menjadi acuan atau tujuan pendidikan bagi para orang tua khususnya di Kabupaten Sambas. Kepala

6 E.Mulyasa, Standar Kompetensi Dan Sertifikasi Guru (Bandung: PT Remaja Rosdakarya Offset, 2012).

7 Erjati Abas, Magnet Kepemimpinan Kepala Madrasah Terhadap Kinerja Guru (Jakarta: PT Elex Media Kompotindo, 2017).

${ }^{8}$ Imam Nur Faozi, 'Peran Kepala Madrasah Sebagai Supervisor Madrasah Ibtidaiyah Istiqomah Sambas PURBALINGGA' (Pascasarjana UIN Sunan Kalijaga Yogyakarta, 2016).

Al-Madrasah: Jurnal Ilmiah Pendidikan Madrasah Ibtidaiyah Vol. 5, No. 2, Januari-Juni 2021 
Arnadi, Purniadi Putra, Hamidah : Pengaruh Supervisi Kepala Madrasah dan Kompetensi Guru Terhadap Kinerja Guru Madrasah Ibtidaiyah Negeri seKabupaten Sambas

madrasah memahami bahwa dengan kualitas sistem dan layanan tentu banyak mendatangkan berbagai keuntungan. Selain kepercayaan masyarakat yang dibuktikan dengan makin meningkatnya animo masyarakat yang ingin menghadiahkan pendidikan terbaik bagi putra- putrinya untuk bersekolah di MIN Kabupaten Sambas Kalimantan Barat. Dengan demikian hal ini merupakan pengaruh dari pengelolaan manajemen kepala Madrasah untuk memberikan pengakuan kepada masyarakat serta kualitas dan kinerja guru sangat antusias dalam membangun pendidikan dasar Islam di Kabupaten Sambas.

Berdasarkan latar belakang masalah penelitian ini: (1) pengaruh supervisi kepala sekolah dengan kinerja guru MIN Kabupaten Sambas, (2) pengaruh kompetensi guru terhadap kinerja guru di Madrasah Ibtidaiyah Negeri Se-Kabupaten Sambas dan (3) adakah pengaruh supervisi kepala sekolah dan kompetensi guru terhadap kinerja guru di MIN Se-Kabupaten Sambas.

\section{METODE PENELITIAN}

Penelitian ini menggunakan penelitian kuantitatif dengan jenis penelitian deskriptif. Lokasi penelitian ini di tiga Madrasah Ibtidaiyah Negeri di Kabupaten Sambas Propinsi Kalimantan Barat yaitu: MIN 1 Sambas, MIN 2 Sambas dan MIN 3 Sambas. Peneliti memilih 3 MIN di Kabupaten Sambas karena ke tiga Madrasah ini sudah melakukan supervisi kepala madrasah. Objek atau subjek berkaitan dengan penelitian yang akan dilakukan, populasi dalam penelitian ini adalah seluruh guru MIN Kabupaten Sambas berjumlah 94 orang termasuk Kepala Madrasah dan guru tidak tetap (GTT).

Instrumen penelitian ini menggunakan kuesioner, observasi dan dokumentasi. Teknik analisis data dalam penelitian ini menggunakan teknis regresi berganda dengan bantuan SPSS Windows versi 23. Adapun tahap pelaksananan analisis meliputi : (1) analisis deskriptif, (2) uji persyaratan analisis, (3) uji asumsi klasik, dan (4) uji hipotesis.

\section{HASIL DAN PEMBAHASAN}

Adapun dalam pembahasan ini MIN Se-Kabupaten Sambas ada beberapa temuan penelitian yang didapat melalui dokumentasi dari sekolah dan kuesioner yang dijawab oleh guru adalah sebagai berikut; Skor supervisi kepala madrasah MIN Se-Kabupaten Sambas termasuk sedang, dengan jumlah 36 orang, kriteria dengan nilai tinggi berjumlah 17 orang sedangkan untuk kategori rendah 15 orang. Berdasarkan pada tabel di atas 4.15 supervisi kepala madrasah MIN SeKabupaten Sambas memiliki sejumlah sampel sebanyak 68 guru, p supervisi kepala madrasah dengan kategori rendah sebanyak 15 guru (22\%), untuk kategori sedang sebanyak 36 guru dengan persentasi 53\% dan untuk kategori 
Arnadi, Purniadi Putra, Hamidah : Pengaruh Supervisi Kepala Madrasah dan Kompetensi Guru Terhadap Kinerja Guru Madrasah Ibtidaiyah Negeri seKabupaten Sambas

tinggi sebanyak 17 guru dengan persentasi (25\%). Dengan demikian dapat disimpulkan bahwa, kecenderungan supervisi kepala madrasah MIN SeKabupaten berada pada kategori sedang yaitu sebanyak 36 guru (53\%), dari jumlah sampel yang berjumlah 68 guru.

Sedangkan berdasarkan dari hasil penelitian tentang variabel kompetensi guru pada kriteria sedang, sebanyak 44 orang guru dengan persentasi $65 \%$ sedangkan untuk kategori tinggi sebanyak 15 guru tingkat persentasinya sebesar $22 \%$ dan untuk kategori rendah sebanyak 9 orang guru dengan persentasi $13 \%$. Untuk variabel kinerja paling banyak dengan kriteria sedang, adalah dengan jumlah 78 orang guru dengan persentasi $78 \%$ sedangkan untuk kategori tinggi sebanyak 10 guru tingkat persentasinya sebesar $15 \%$ dan untuk kireteria rendah sebanyak 5orang guru dengan persentasi $7 \%$.

\section{Pengaruh Supervisi Kepala Madrasah Berpengaruh Terhadap Kinerja Guru MIN Kabupaten Sambas}

Temuan penelitian menunjukkan adanya pengaruh supervisi kepala madrasah dengan kinerja guru yang memiliki nilai signifikansinya sebesar 0.029 yang mana $\mathrm{p}=0,029<0,05 \mathrm{H}_{\mathrm{o}}$ di ditolak dan $\mathrm{H}_{1}$ terima, jadi hasil penelitian menjelaskan bahwa adanya pengaruh signifikan supervisi kepala madrasah terhadap kinerja guru. Besarnya korelasi koefisien supervisi kepala madrasah $\left(\mathrm{X}_{1}\right)$ terhadap kinerja guru $(\mathrm{Y})$. Pengaruh supervisi kepala madrasah sebesar 0.070 artinya memiliki pengertian bahwa $7 \%$ sumbangan supervisi kepala sekolah dengan kinerja guru faktor lain memiliki 93\%. Berdasarkan dari hasil penelitian diperkuat oleh hasil wawancara beberapa guru bahwa dalam supervisi kepala madrasah memberikan pengaruh terhadap kinerja guru sebab kualitas kinerja guru memang terukur dan bisa memberikan dampak yang signifikan. Berdasarkan dari nilai besarnya pengaruh supervisi kepala madrasah yang hanya $7 \%$ dipengaruhi oleh beberapa faktor antara lain, kinerja dapat meningkat disebabkan dari insentif yang diterima oleh guru.

Berdasarkan dari temuan di atas bahwa menurut ${ }^{9}$, dalam teori ini menyatakan bahwa Tingkat keberhasilan kinerja guru, dapat diketahui melalui kegiatan supervisi pendidikan yang dilakukan oleh kepala sekolah dengan menggunakan berbagai teknik supervisi. Kegiatan supervisi yang dilakukan kepala sekolah pada dasrnya merupakan

\footnotetext{
9 Supardi, 'Pengaruh Supervisi Kepala Sekolah Pada Peningkatan Kinerja Guru', Studia Didaktika: Jurnal Ilmiah Bidang Pendidikan, 11.1 (2017), 63-70.
}

Al-Madrasah: Jurnal Ilmiah Pendidikan Madrasah Ibtidaiyah Vol. 5, No. 2, Januari-Juni 2021 
Arnadi, Purniadi Putra, Hamidah : Pengaruh Supervisi Kepala Madrasah dan Kompetensi Guru Terhadap Kinerja Guru Madrasah Ibtidaiyah Negeri seKabupaten Sambas

pemberian bantuan atau pertolongan dalam mengembangkan situasi pembelajaran yang lebih baik di madrasah. Selain itu juga Menurut Hadis ${ }^{10}$ layanan supervisi yang diberikan kepala Sekolah kepada guru di sekolah, memiliki peran strategis dalam mengangkat citra mutu pendidikan di Indonesia. Pembinaan yang dilakukan kepala madrasah dapat dilakukan melalui kegiatan supervisi.

Berdasarkan dari data kuesioner yang diperoleh di lapangan bahwa Sekolah menyiapkan jadwal supervisi jawaban yang diperoleh guru dengan 25 orang menjawab selalu. Hal ini berarti hasil temuan berpengaruh yang signifikansi dengan kinerja guru MIN Sambas. Hasil ini juga membuktikan bahwa sumbangan supervisi kepala madrasah terhadap kinerja guru 93\% yang dipengaruhi oleh faktor yang lain.

Hal ini sependapat dari hasil penelitian ini, ada faktor lain dalam mempengaruhi kinerja guru sesuai dengan pendapat Rahadhini dan Sugiono ${ }^{11}$ menyebutkan bahwa adanya unsur dari dalam diri setiap guru menjadi salah satu faktor pendukung dalam memberikan kontribusi kinerja guru, selain itu faktor dari luar adalah lingkungan. Pentingnya supervisi bagi guru dan pemangku kepentingan adalah untuk memberikan kontribusi peningkatan dan kemampuan memberikan kemudahan agar bisa diakses. ${ }^{12}$

\section{Pengaruh Kompetensi Guru (X2) Terhadap Kinerja Guru (Y) di MIN Negeri Se-Kabupaten Sambas}

Dalam hasil penelitian ini menunjukkan bahwa terdapat pengaruh kompetensi guru terhadap kinerja guru dengan nilai signifikansinya sebesar 0.00 yang mana $\mathrm{p}=0,00<0,05 \mathrm{H}_{\mathrm{o}}$ di ditolak dan $\mathrm{H}_{1}$ terima, jadi terdapat pengaruh yang signifikan dari kompetensi guru terhadap kinerja guru. Korelasi koefisien pengaruh kompetensi guru (X2) terhadap kinerja

\footnotetext{
${ }^{10}$ Miftahul Laili Hasanah and Muhammad Kristiawan, 'Supervisi Akademik Dan Bagaimana Kinerja Guru', Tadbir : Jurnal Studi Manajemen Pendidikan, 3.2 (2019), 97 <https://doi.org/10.29240/jsmp.v3i2.1159>.

${ }^{11}$ Mavis G. Sanders and others, 'Manajemen, Kepemimpinan, Supervisi Pendidikan Vol 1, No. 1, Juli-Desember 2017', American Journal of Education, 1.2 (2017), 233-55 $<$ https://doi.org/10.1086/674374>.

${ }^{12}$ Cik Imah, 'Pengaruh Supervisi Kepal Sekolah Terhadap Kinerja Guru SD Negeri SeKecamatan Air Kumbang Kabupaten Banyuasin', Jurnal Administrasi Pendidikan UM Palembang, 1.2 (2018), 65-77.
}

Al-Madrasah: Jurnal Ilmiah Pendidikan Madrasah Ibtidaiyah Vol. 5, No. 2, Januari-Juni 2021 
Arnadi, Purniadi Putra, Hamidah : Pengaruh Supervisi Kepala Madrasah dan Kompetensi Guru Terhadap Kinerja Guru Madrasah Ibtidaiyah Negeri seKabupaten Sambas

guru (Y) sebesar $0.459(45.90 \%)$ artinya pengaruh antara variabel kompetensi guru $\left(\mathrm{X}_{2}\right)$ terhadap kinerja guru $(\mathrm{Y})$ artinya memiliki kekutan pengaruh antara variabel kompetensi guru $\left(\mathrm{X}_{2}\right)$ terhadap kinerja guru $(\mathrm{Y})$ untuk sisanya $54.10 \%$ yang dipengaruhi oleh faktor yang lain $(100 \%-$ 45.90\%). Berdasarkan temuan penelitian ini tentang kompetensi guru dengan kinerja guru di MIN Kabupaten Sambas dapat disimpulkan bahwa sudah baik di mana hampir sebagian kompetensi hal ini terjadi karena MIN Negeri Kabupaten Sambas selalu berupaya untuk mengembangkan kompetensi guru sesuai dengan kurikulum yang berlaku dan melakukan inovasi-inovasi terbaru dalam mengembangkan kompetensi yang dimilikinya

Sesuai dengan hasil penelitian secara teori bahwa menurut Hary Susanto, ${ }^{13}$ kompetensi guru terhadap motivasi mempunyai pengaruh yang signifikan. Dalam hal ini juga menunjukkan tentang kinerja guru yang baik maka kompetensi guru juga ikut baik. Hasil penelitian ini diperkuat dengan teori Gibson ${ }^{14}$ ada empat kemampuan yang dimiliki guru yaitu kompetensi profesional, kepribadian, sosial dan pedagogi. Mulyasa ${ }^{15}$ mengemukakan kompetensi guru merupakan perpaduan antara kemampuan personal, keilmuan, teknologi, sosial, dan spritual yang secara kaffah membentuk kompetensi standar profesi guru, yang mencakup penguasaan materi, pemahaman terhadap peserta didik, pembelajaran yang mendidik, pengembangan pribadi dan profesionalisme. Guru yang profesional ${ }^{16}$ adalah guru yang memiliki

\footnotetext{
13 Hary Susanto, 'Kinerja Guru Sekolah Menengah Kejuruan', Jurnal Pendidikan Vokasi, 2.2 (2012).

${ }^{14}$ omang Septia Cahya Ningrum, 'Pengaruh Kompetensi Guru dengan Kinerja Guru SMP Negeri 6 Singaraja', 7.12 (2016).

${ }_{15}$ H Ade Sobandi, 'Pengaruh Kompetensi Guru Terhadap Kinerja Mengajar Guru SMKN Bidang Keahlian Bisnis dan Manajemen Di Kota Bandung', Bisnis Manajemen, 9.17 (2010).

${ }^{16}$ Purniadi Putra, 'Pengaruh Kinerja Guru Bersertifikasi Dan Belum Bersertifikasi Terhadap Prestasi Belajar Siswa Di MIN Se-Kabupaten Sambas', JMIE (Journal of Madrasah Ibtidaiyah Education), $1.1 \quad$ (2017), 14-26 <http://ejournal.adpgmiindonesia.com/index.php/jmie>.
}

Al-Madrasah: Jurnal Ilmiah Pendidikan Madrasah Ibtidaiyah Vol. 5, No. 2, Januari-Juni 2021 
Arnadi, Purniadi Putra, Hamidah : Pengaruh Supervisi Kepala Madrasah dan Kompetensi Guru Terhadap Kinerja Guru Madrasah Ibtidaiyah Negeri seKabupaten Sambas

mutu yang memiliki standarisasi dalam kemampuan memberikan ilmu. Kompetensi guru tersebut merupakan kelebihan yang dimiliki setiap guru. ${ }^{17}$

Castetter berpendapat bahwa ada empat kriteria dalam kinerja guru yang diungkapan oleh Mulyasa, ${ }^{18}$ diantaranya; (1) karakter setiap individu, (2) proses, (3) hasil, dan (4) kolaborasi antara watak setiap individu, proses, dan hasil. Keahlian seorang guru akan meningkat jika ditempatkan pada pekerjaan yang sesuai. Hal ini akan memberikan implikasi terhadap mutu dan kualitas sekolah dalam pengembangan pendidikan.

\section{Pengaruh Supervisi Kepala Madrasah, Kompetensi Guru Terhadap Kinerja Guru}

Dalam hasil penelitian ini menunjukkan bahwa terdapat pengaruh supervisi kepala madrasah (X1) dan kompetensi guru (X2) terhadap kinerja guru (Y) sebesar 0.00 artinya $\mathrm{p}=0,00<0,05 \mathrm{H}_{\mathrm{o}}$ di ditolak dan $\mathrm{H}_{1}$ terima, jadi terdapat pengaruh yang signifikan dari supervisi kepala madrasah dan kompetensi guru terhadap kinerja guru. Sedangkan besarnya korelasi koefisien supervisi kepala madrasah $\left(\mathrm{X}_{1}\right)$ dan kompetensi guru $\left(\mathrm{X}_{2}\right)$ terhadap kinerja guru $(\mathrm{Y})$. Selain itu besarnya nilai pengaruh supervisi kepala madrasah sebesar 0.521 artinya mengandung pengertian bahwa $52.10 \%$ sumbangan supervisi kepala madrasah dan kompetensi guru terhadap kinerja guru, sedangkan sisanya $47 \%$ yang dipengaruhi oleh faktor yang lain (100\%-52.10\%).

Berdasarkan temuan penelitian dapat disimpulkan bahwa sudah baik di mana hampir sebagian kompetensi hal ini terjadi karena MIN Negeri Kabupaten Sambas selalu berupaya untuk mengembangkan kompetensi guru sesuai dengan kurikulum yang berlaku dan melakukan inovasi terbaru dalam mengembangkan kompetensi yang dimilikinya. Hasil penelitian di lapangan membuktikan bahwa kualitas akan baik jika

\footnotetext{
${ }^{17}$ kepala Madrasah, Motivasi Kerja, And D A N Kompetensi, 'Pengaruh Persepsi Guru Terhadap Kepemimpinan Guru Terhadap Kinerja Guru Di Madrasah Tsanawiyah Negeri Se-Kabupaten Sambas', Jurnal Pendidikan Inspiratif, 9.2 (2018), 110-27.

18 Lilik Kurniasih, 'Pengaruh Kompetensi Guru, Iklim Organisasi Dan Supervisi Akademik Kepala Sekolah Terhadap Kinerja Guru Mata Pelajaran Pendidikan Agama Islam Sekolah Dasar Negeri Se-Kecamatan Sukoharjo Tahun Pelajaran 2017/ 2018', 187 (p. Hlm.118).', 1.1 (2018).
}

Al-Madrasah: Jurnal Ilmiah Pendidikan Madrasah Ibtidaiyah Vol. 5, No. 2, Januari-Juni 2021 
Arnadi, Purniadi Putra, Hamidah : Pengaruh Supervisi Kepala Madrasah dan Kompetensi Guru Terhadap Kinerja Guru Madrasah Ibtidaiyah Negeri seKabupaten Sambas

supervisi kepala madrasah dan kompetensi guru akan meningkat perbaikan kualitas kinerja guru.

Hal ini sejalan dengan pendapat Aslamiah ${ }^{19}$ menyebutkan bahwa, terdapat hubungan antara pelaksanaan supervisi akademik kepala sekolah terhadap kinerja guru di MTsN Imadun Najah. Pelaksanaan supervisi akademik sangat penting dilakukan oleh kepala sekolah, karena salah satu faktor yang menjadikan sekolah baik dan berkualitas itu adalah sumber daya manusia yang ada di sekolah tersebut terutama guru. Hal ini mengisyaratkan bahwa supervisi akademik kepala sekolah merupakan faktor yang sangat penting dan perlu diperhatikan dalam peningkatan kompetensi pedagogik guru.

Pentingnya supervisi kepala madrasah dalam peningkatan kualitas dan mutu kinerja guru. Hal ini akan memberikan evaluasi diri terhadap kinerja guru dalam bidang pendidikan. Peningkatan pengembangan kualitas guru diperlukan beberapa kompetensi. ${ }^{20}$ Studi sebelumnya menurut Mohd Zaki ${ }^{21}$ menemukan bahwa supervisi terhadap guru akan mengembangkan profesionalisme dan kinerja mengajar.

Berdasarkan dari beberapa hasil temuan penelitian ini sesuai dengan beberapa hasil wawancara dengan guru menyebutkan bahwa kinerja guru banyak berhasil karena didukung oleh faktor kompetensi guru dan supervisi yang diberikan oleh setiap madrasah, hal ini juga memberikan motivasi guru dalam meningkatkan kualitas dan etos kerja guru.

\section{KESIMPULAN}

Terdapat pengaruh positif dengan hasil yang rendah dalam supervisi kepala madrasah terhadap kinerja guru 7\%. Besarnya pengaruh digambarkan koefisien determinasi $\mathrm{R}$ ( $R$ square) adalah 0.070 , artinya supervisi kepala sekolah berkontribusi dengan pengaruh kinerja guru sebanyak $7 \%$ dan sumbangan dari faktor lain sebesar $93 \%$. Penambahan setiap adanya supervisi memberikan tambahan skor kinerja guru 0.360. Dengan demikian supervisi kepala madrasah dari hasil kinerja guru MIN Se-Kabupaten Sambas. Adanya

\footnotetext{
${ }^{19}$ Hasanah and Kristiawan.

${ }^{20}$ Da'i Wibowo.

${ }^{21}$ Kazi Enamul Hoque and others, 'Relationships Between Supervision and Teachers' Performance and Attitude in Secondary Schools in Malaysia', SAGE Open, 10.2 (2020) <https://doi.org/10.1177/2158244020925501>.
}

Al-Madrasah: Jurnal Ilmiah Pendidikan Madrasah Ibtidaiyah Vol. 5, No. 2, Januari-Juni 2021 
Arnadi, Purniadi Putra, Hamidah : Pengaruh Supervisi Kepala Madrasah dan Kompetensi Guru Terhadap Kinerja Guru Madrasah Ibtidaiyah Negeri seKabupaten Sambas

kontribusi dengan kategori tinggi kompetensi guru terhadap kinerja guru sebesar 45,90\% artinya adalah kompetensi secara kepribadian, profesional, sosial dan pedagogi) berkontribusi dengan kinerja guru 45,90\%.

\section{SARAN DAN REKOMENDASI}

Berdasarkan hasil penelitian ini peningkatan kinerja guru perlu ditingkatkan untuk memenuhi standar mutu pendidikan sekolah. Pelaksanaan supervisi kepala madrasah ini harus setiap semester dilakukan dan secara langsung berkerjasama dengan pengawas sekolah dan lembaga tinggi lainnya dalam memberikan masukkan dalam hal memperbaiki sistem pembelajaran. Guru harus berinovasi dalam membangun pengetahuan yang lebih update untuk bekal menstransfer ilmu terhadap siswa.

\section{DAFTAR PUSTAKA}

Abas, Erjati, Magnet Kepemimpinan Kepala Madrasah Terhadap Kinerja Guru (Jakarta: PT Elex Media Kompotindo, 2017)

Da'i Wibowo, 'Kompetensi Pedagogik Guru Terhadap Kinerja Guru' (Universitas Negeri Semarang, 2009)

E.Mulyasa, Standar Kompetensi Dan Sertifikasi Guru (Bandung: PT Remaja Rosdakarya Offset, 2012)

Faozi, Imam Nur, 'Peran Kepala Madrasah Sebagai Supervisor Madrasah Ibtidaiyah Istiqomah Sambas Purbalingga' (Pascasarjana UIN Sunan Kalijaga Yogyakarta, 2016)

Hasanah, Miftahul Laili, and Muhammad Kristiawan, 'Supervisi Akademik Dan Bagaimana Kinerja Guru', Tadbir : Jurnal Studi Manajemen Pendidikan, 3.2 (2019), 97 <https://doi.org/10.29240/jsmp.v3i2.1159>

Hoque, Kazi Enamul, Husaina Banu Bt Kenayathulla, Malar Vili D/O Subramaniam, and Reazul Islam, 'Relationships Between Supervision and Teachers' Performance and Attitude in Secondary Schools in Malaysia', SAGE Open, 10.2 (2020) <https://doi.org/10.1177/2158244020925501>

Imah, Cik, 'Pengaruh Supervisi Kepal madrasah Terhadap Kinerja Guru SD Negeri Se- Kecamatan Air Kumbang Kabupaten Banyuasin', Jurnal Administrasi Pendidikan UM Palembang, 1.2 (2018), 65-77

Kaspullah, Purniadi Putra, and Imelda Wulandari, 'Pengaruh Persepsi Guru Terhadap Kepemimpinan Guru Terhadap Kinerja Guru di Madrasah 
Arnadi, Purniadi Putra, Hamidah : Pengaruh Supervisi Kepala Madrasah dan Kompetensi Guru Terhadap Kinerja Guru Madrasah Ibtidaiyah Negeri seKabupaten Sambas

Tsanawiyah Negeri Se-Kabupaten Sambas', Jurnal Pendidikan Inspiratif, 9.2 (2018), 110-27

Kurniasih, Lilik, 'Pengaruh Kompetensi Guru, Iklim Organisasi Dan Supervisi Akademik Kepala Sekolah Terhadap Kinerja Guru Mata Pelajaran Pendidikan Agama Islam Sekolah Dasar Negeri Se-Kecamatan Sukoharjo Tahun Pelajaran 2017/ 2018', 187 (p. Hlm.118).', 1.1 (2018)

Mawarni, Riska, and Chiar Sukmawati, 'Supervisi Akademik di Sekolah Menengah Atas Negeri 1 Pemangkat Kabupaten Sambas', Pendidikan Dan Pembelajaran Khatulistiwa, 6.1 (2017), 1-17

Moh Uzer Usman, Menjadi Guru Profesional (Bandung: PT Remaja Rosdakarya, 2010)

Nana Sudjana, Dasar-Dasar Proses Belajar Mengajar (Bandung: Sinar Baru, 2002)

Ningrum, omang Septia Cahya, 'Pengaruh Kompetensi Guru Terhadap Kinerja Guru SMP Negeri 6 Singaraja’, 7.12 (2016)

Nomor. 14 Tahun 2005, Dosen, Tentang Guru dan, Undang-Undang R.I (Jakarta, 2005), p. 2

Putra, Purniadi, 'Pengaruh Kinerja Guru Bersertifikasi Dan Belum Bersertifikasi Terhadap Prestasi Belajar Siswa Di MIN Se-Kabupaten Sambas', JMIE (Journal of Madrasah Ibtidaiyah Education), 1.1 (2017), 14-26 <http://e-journal.adpgmiindonesia.com/index.php/jmie>

Sanders, Mavis G., Dian Lukmansyah, Rahma Danniarti, and Dewi Susanti, Moh. Rois, Fartika Ifriqia, 'Supervisi Pendidikan Volume 1, No. 1, JuliDesember 2017', American Journal of Education, 1.2 (2017), 233-55 <https://doi.org/10.1086/674374>

Supardi, 'Pengaruh Supervisi Kepala Madrasah Dalam Peningkatan Kinerja Guru', Studia Didaktika: Jurnal Ilmiah Bidang Pendidikan, 11.1 (2017), 63-70

Susanto, Hary, 'Faktor-Faktor Yang Mempengaruhi Kinerja Guru Sekolah Menengah Kejuruan', Jurnal Pendidikan Vokasi, 2.2 (2012)

Al-Madrasah: Jurnal Ilmiah Pendidikan Madrasah Ibtidaiyah Vol. 5, No. 2, Januari-Juni 2021 